\title{
PENURUNAN KADAR BOD, COD dan TSS PADA AIR LIMBAH DOMESTIK DENGAN SISTEM CONSTRUCTED WETLAND MENGGUNAKAN TANAMAN KAYU APU (Pistia stratiotes L.) \\ REDUCTION OF BOD, COD and TSS LEVELS IN DOMESTIC WASTEWATER WITH CONSTRUCTED WETLAND SYSTEM USING APU WOOD PLANT (Pistia stratiotes L.)
}

\author{
Rizki Amalia Priska Tampubolon ${ }^{1}$, Laila Febrina ${ }^{2}$, Ira Mulyawati ${ }^{3}$ \\ ${ }^{1}$ Teknik Lingkungan, Fakultas Teknik, Jurusan Universitas Sahid Jakarta, Jl. Prof. Dr. Soepomo, SH No.84 \\ Tebet Jakarta, Email : priskatampubolon@gmail.com \\ ${ }^{2}$ Program Studi Teknik Lingkungan, Fakultas Teknik, Universitas Sahid Jakarta, Jl. Prof. Dr. Soepomo, SH No.84 \\ Tebet Jakarta, Email : Laila Febrina@usahid.ac.id \\ ${ }^{3}$ Program Studi Teknik Lingkungan, Fakultas Teknik, Universitas Sahid Jakarta, Jl. Prof. Dr. Soepomo, SH No.84 \\ Tebet Jakarta, Email : iramulyawati@gmail.com
}

\begin{abstract}
ABSTRAK
Air limbah domestik berasal dari usaha dan atau kegiatan permukiman, rumah makan, perkantoran, perniagaan, apartemen, dan asrama. Pencemaran air sungai $60 \%$ - 70\% berasal dari limbah domestik, dengan kontribusi pencemar di DAS 60\% berasal dari limbah domestik (sanitasi, sampah, detergen); $30 \%$ limbah industri; dan 10\% limbah pertanian dan peternakan. Kayu apu (Pistia stratiotes L.) merupakan salah satu tumbuhan fitoremediator yaitu memiliki kemampuan untuk mengolah limbah, baik itu berupa logam berat, zat organik maupun anorganik, mudah ditemukan, dan ekonomis. Sistem pengolahan air limbah dengan Sistem Lahan Basah Buatan (Constructed Wetlands) menjadi rekomendasi untuk pengolahan limbah yang ekologis karena karakteristik limbah domestik yang biodegradable. Penelitian ini dilakukan skala laboratorium dengan menggunakan 4 buah reaktor. Perlakuan pertama dengan variasi jumlah Kayu Apu (Pistia stratiotes. L) pada tiap bak ember, yaitu 0, 4, 8 dan 12. Perlakuan kedua dengan variasi waktu kontak tanaman, yaitu hari ke-3, hari ke-6, ke-9 dan hari ke-12. Kemudian diukur kadar BOD, COD dan TSS masing masing tiap bak. Hasil penelitian menunjukkan bahwa jumlah tanaman terbaik dalam menurunkan beban pencemar adalah 12 tanaman. Pengaruh waktu kontak tanaman Kayu Apu (Pistia stratiotes. L) yang paling efisien yaitu pada hari ke12 dengan hasil paling maksimal mencapai BOD $10 \mathrm{mg} / \mathrm{L}$ (95,83\%), COD 15,97 mg/L (95,01\%), dan TSS 17,66 mg/L (96,09\%).
\end{abstract}

Kata kunci: Limbah air domestik, Fitoremediator, Constructed wetland, Kayu Apu

\begin{abstract}
Domestic waste water comes from businesses and / or residential activities, restaurants, offices, businesses, apartments and dormitories. River water pollution 60\% - 70\% comes from domestic waste, with the contribution of pollutants in the watershed $60 \%$ comes from domestic waste (sanitation, garbage, detergents); $30 \%$ industrial waste; and 10\% of agricultural and livestock waste. Apu wood (Pistia stratiotes L.) is a phytoremediator plant that has the ability to treat waste, whether in the form of heavy metals, organic or inorganic substances, easy to find, and economical. The wastewater treatment system with the Constructed Wetlands System becomes a recommendation for treating ecological waste due to the characteristics of biodegradable domestic waste. This research was conducted on a laboratory scale using 4 reactors. The first treatment with variations in the amount of Apu (Pistia stratiotes. L) in each bucket, which is $0,4,8$ and 12. The second treatment with variations in the contact time of plants, namely the 3rd day, 6th, 9th day and 12th day. Then the levels of BOD, COD and TSS were measured for each tank. The results showed that the best number of plants in
\end{abstract}


reducing pollutant load was 12 plants. The most efficient influence of contact time of Apu (Pistia stratiotes. L) plants on the 12th day with maximum results reaching BOD $10 \mathrm{mg} / \mathrm{L}(95.83 \%), C O D$ $15.97 \mathrm{mg} / \mathrm{L}(95.01 \%)$, and TSS $17.66 \mathrm{mg} / \mathrm{L}(96.09 \%)$.

Keywords: Domestic waste water, Phytoremediator, Constructed wetland, Kayu Apu

\section{Pendahuluan}

Air adalah kebutuhan yang sangatpenting bagi semua mahkluk hidup.Semakin hari kebutuhan akan air bersihsemakin meningkat denganbertambahnya jumlah manusia. Namun kebutuhan akan air bersih tidak selaras dengan jumlah air yang tersedia, dikarenakan banyaknya sumber air bakuyang sudah tercemar. Seperti air danau,air sungai, dan air tanah. Manusiasangat membutuhkan air, tetapi manusiajuga yang mencemarinya. Maka dari itu perlunya pengolahan air limbah sebelum di buang ke badan sungai, agarmengurangi beban pencemaran pada air.

Pencemaran air sungai 60\% - 70\% berasal dari limbah domestik(Ismuyanto,2010), dengan kontribusipencemar di DAS $60 \%$ berasal darilimbah domestik (sanitasi, sampah, detergen); $30 \%$ limbah industri; dan10\% limbah pertanian dan peternakan.Oleh karenanya penting untukmemperbaiki sistem sanitasi, untukmengurangi beban pencemar airpermukaan yang dimanfaatkan sebagaisumber air. Metode pengolahan dapatberupa metode pengolahan secarafisika, kimia dan biologi. Dari ketigametode tersebut yang dinilai efisiendalam menurunkan zat organik dalamair limbah dengan biaya relatif murah adalah metode pengolahan biologis, atau dari beberapa metode pengolahanbiologis, penggunaan tumbuhan air atau fitoteknologi. Fitoteknologi adalahpenerapan ilmu dan teknologi untukmengkaji dan menyiapkan solusimasalah lingkungan denganmenggunakan tumbuhan, penggunaantanaman air dapat memberikantambahan oksigen dan menyerap zat pencemar secara langsung.

Pengolahan air limbah ini menggunakan sistem ConstructedWetlands (CWs). Tujuannya adalah untuk memperbaiki kualitas air dan mengurangi efek berbahaya dari limbah, serta menyumbang upaya konservasi air. Sistem pengolahan air limbah dengan Sistem Lahan Basah Buatan (Constructed Wetlands) menjadi rekomendasi untuk pengolahan limbah yang ekologis karena karakteristik limbah domestik yang biodegradable (Zidan et al, 2015).

Constructed Wetlands adalahsalah satu rekayasa sistem pengolah limbah yang dirancang dan dibangun dengan melibatkan tanaman air, tanahatau media lain, dan kumpulan mikroba terkait. Dalam penelitian ini saya menggunakan tanaman Kayu Apu (Pistia stratiotes L.). Secara umum tanaman kayu apu (Pistia stratiotes $L$.) adalah tanaman air yang biasa dijumpai mengapung di perairan tenang ataukolam. Kayu apu terkenal sebagai tumbuhan pelindung akuarium.Tumbuhan ini adalah satu-satunyaanggota marga Pistia. (Safitri, 2009).

Kayu apu (Pistia stratiotes L.) juga merupakan salah satu tumbuhan fitoremediator yaitu tumbuhan yang memiliki kemampuan untuk mengolah limbah, baik itu berupa logam berat, zat organik maupun anorganik, mudah ditemukan, dan ekonomis.

Air limbah domestik mengandungzat organik dan zat anorganik, yang kandungannya dapat diketahui denganmenguji beberapa parameter air limbah domestik seperti $\mathrm{pH}, \mathrm{COD}$, BOD, TSS, sesuai dengan Peraturan MenteriLingkungan Hidup Kehutanan Republik Indonesia Nomor : P.68/Menlhk /Setjen/Kum.1/8/2016.

Tujuan penelitian ini adalah untuk menurunkan kadar pencemar dalam air limbah domestik, dengan variasi waktu kontak dan jumlah tanaman Kayu Apu (Pistia stratiotes L.) dengan mengggunakan constructed wetland. 


\section{Metode Penelitian}

\subsection{Populasi dan Sampel}

Populasi tanaman air Kayu Apu (Pistia stratiotes L.) yang dijadikan adsorben adalah keseluruhan dari tanaman Kayu Apu. Populasi air yang dapat dianalisis adalah keseluruhan air yang bersumber dari sampel air limbah domestik. Berikut gambar constructed wetland dan variasi jumlah tanaman kayu apu (Pistia stratiotes L.). Berikut gambar constructed wetland dan variasi jumlah tanaman kayu apu (Pistia stratiotes $L$.$) .$
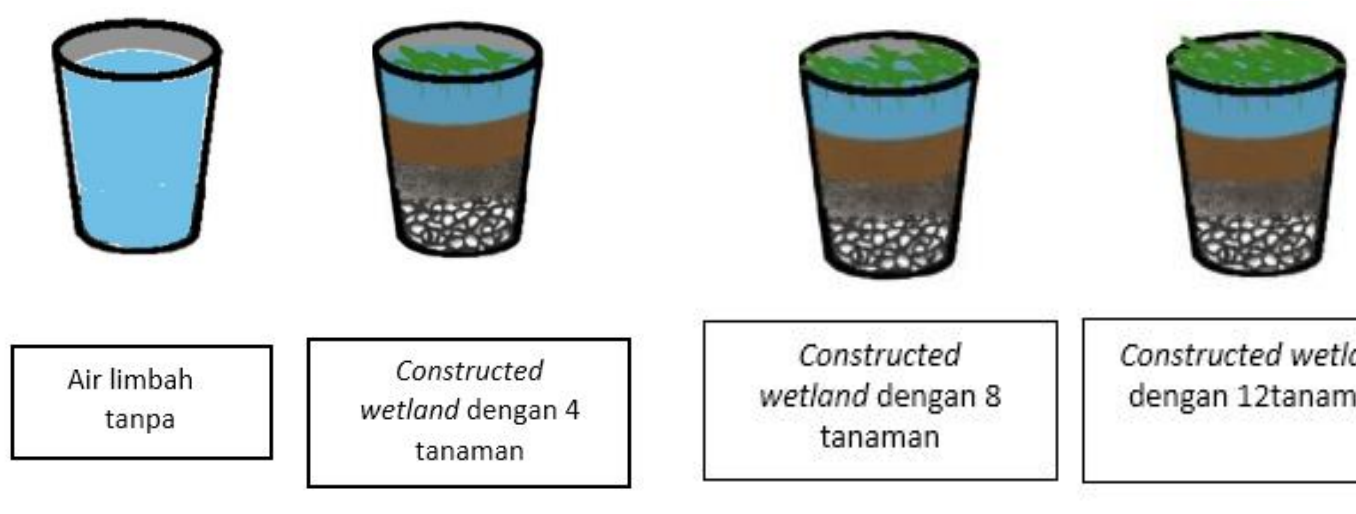

Constructed wetland dengan 12 tanaman

Gambar 1. Constructed wetland dan variasi jumlah tanaman kayu apu (Pistia stratiotes L.)

\subsection{Metode Pengambilan Sampel}

Metode pengambilan sampel pada penelitian ini menggunakan metode probability sampling yakni pengambilan sampel secara random atau acak. Seluruh anggota populasi diasumsikan memiliki kesempatan yang sama untuk terpilih menjadi sampel penelitian.

\subsection{Metode Pengumpulan Data}

Metode pengumpulan data dalam penelitian ini menggunakan penelitian lapangan yakni dengan melakukan pengukuran langsung terhadap daya adsorpsi Kayu Apu (Pistia stratiotes L.) pada COD, BOD dan TSS dalam air limbah di UPTD Laboratorium Lingkungan Dinas Lingkungan Hidup Kota Bekasi.

\subsection{Analisis Data}

Air limbah domestik mengandung zat organik dan zat anorganik, yang kandungannya dapat diketahui dengan menguji beberapa parameter air limbah domestik seperti $\mathrm{pH}$, COD, BOD, TSS, Minyak dan Lemak, Amonia, total coliform sesuai dengan Peraturan Menteri Lingkungan Hidup Kehutanan Republik Indonesia Nomor: P.68/Menlhk/Setjen/Kum.1/8/2016.

Namun pada penelitian ini saya hanya menguji parameter COD, BOD dan TSS dikarenakan kadarnya yang melebihi baku mutu air limbah domestik. Parameter $\mathrm{pH}$, Minyak dan Lemak, Amonia, dan Total Coliform tidak saya uji dikarenakan hasilnya masih dibawah buku mutu air limbah domestik. Ini terjadi karena sampel air limbah domestik yang saya gunakan adalah air limbah domestik yang berasal dari laboratorium tempat saya melakukan penelitian. Dimana air limbah domestik tersebut memiliki nilai pH yang normal, tidak memiliki bau yang menyengat, mengandung minyak dan lemak yang sedikit karena tidak ada kegiatan yang menghasilkan minyak dan lemak, dan tidak mengandung bakteri pencemar yang berlebihan karena adanya septic tank tempat pembuangan tinja dan urin. Maka dari itu nilai kadar beberapa parameter masih di bawah baku mutu.

\subsection{Tahapan Penelitian}


Penelitian ini menggunakan Tanaman Kayu Apu (Pistia stratiotes L.) yang memiliki usia 4 minggu dan tanaman yang digunakan memiliki jumlah daun berdekatan, yaitu yang berjumlah 7-8 helai daun. Setelah tanaman Kayu Apu (Pistia stratiotes L.) diselidiki, dicuci dengan air sampai bersih untuk menghilangkan kotoran dalam akar tanaman Kayu Apu (Pistia stratiotes L.). Sebelum dilakukan percobaan, maka tanaman perlu diaklimatisasi terlebih dahulu sebagai penyesuaian suatu organisme untuk beradaptasi pada lingkungan yang baru. Tanaman diaklimatisasi dengan cara dimasukkan kedalam ember yang berisi air bersih selama kurang lebih 1 minggu dan setelah itu dimasukkan kedalam ember yang berisi air limbah selama kurang lebih 1 minggu. Tujuannya adalah untuk menstabilkan keadaan lingkungan untuk memulai proses biofilter. Berikut adalah gambar tahapan penelitian.

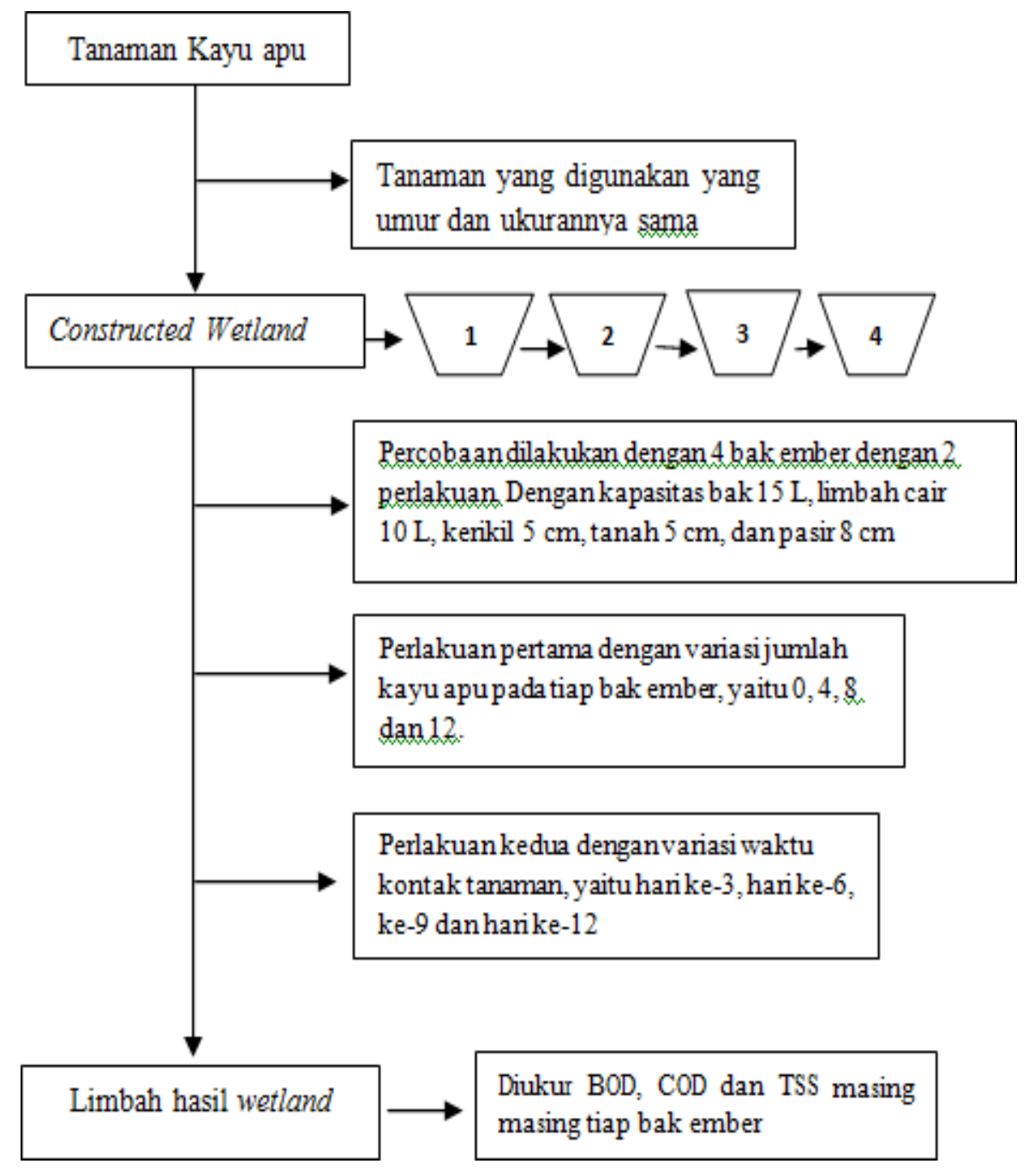

Gambar 2. Tahapan Penelitian

\section{Hasil dan Pembahasan}

\subsection{Hasil Penelitian}

Krisis air bersih dapat kita lihat dengan banyaknya sumber air baku yang tercemar. Sumbernya bisa jadi dari kegiatan industri dan rumah tangga. Maka dari itu untuk mengurangi beban pencemar sungai sebagai salah satu sumber air baku. Penelitian ini dilakukan dengan cara fitoteknologi yaitu penggunaaan tanaman air dengan sistem constructed wetland (lahan basah). 
Penelitian ini menggunakan sampel air limbah domestik dimana air limbah ini terindikasi bercampur dengan limbah B3. Dikarenakan tidak adanya IPAL pada instansi tersebut, maka penampungan limbah harus dilakukan secara manual. Dikarenakan penampungan limbah yang manual, bukan tidak mungkin jika ada sisa limbah yang akan ikut terbuang ke saluran pembuangan. Maka dari itu untuk memastikannya perlu dilakukan uji air limbah terlebih dahulu.

Pada uji ini saya menganalisa limbah tersebut menggunakan Peraturan Menteri Lingkungan Hidup lampiran 47 Nomor 5 tahun 2014 tentang air limbah yang belum memiliki baku mutu air limbah yang ditetapkan, karena sampel yang saya gunakan merupakan limbah campuran, yaitu limbah domestik yang terindikasi limbah B3. Maka dari itu saya melakukan analisa terhadap air limbah ini terlebih dahulu untuk menentukan apakah ini limbah domestik atau limbah B3. Berikut adalah hasil uji laboratorium dapat dilihat pada tabel 1.

Tabel 1. Kualitas Awal Limbah

\begin{tabular}{clrrr}
\hline No & Paramater & Satuan & Hasil Uji & Baku Mutu \\
\hline 1 & Temperatur & $\mathrm{oC}$ & 27,4 & 40 \\
2 & TSS & $\mathrm{mg} / \mathrm{L}$ & 436,44 & 400 \\
3 & TDS & $\mathrm{mg} / \mathrm{L}$ & 1748 & 4000 \\
4 & $\mathrm{pH}$ & - & 6,06 & $6,0-9,0$ \\
5 & COD & $\mathrm{mg} / \mathrm{L}$ & 320 & 300 \\
6 & Besi Terlarut & $\mathrm{mg} / \mathrm{L}$ & 2,12 & 10 \\
7 & Mangan Terlarut & $\mathrm{mg} / \mathrm{L}$ & 1,06 & 5 \\
8 & Tembaga Terlarut & $\mathrm{mg} / \mathrm{L}$ & $<0,0036$ & 3 \\
9 & Seng Total & $\mathrm{mg} / \mathrm{L}$ & 0,131 & 10 \\
10 & Krom Total & $\mathrm{mg} / \mathrm{L}$ & 0,226 & 1 \\
11 & Kobalt Total & $\mathrm{mg} / \mathrm{L}$ & $<0,1622$ & 0,6 \\
12 & Kadmium Total & $\mathrm{mg} / \mathrm{L}$ & $<0,0057$ & 0,1 \\
13 & Timbal Total & $\mathrm{mg} / \mathrm{L}$ & $<0,0560$ & 1 \\
14 & Krom Heksavalen & $\mathrm{mg} / \mathrm{L}$ & 0,018 & 0,5 \\
15 & Nitrit & $\mathrm{mg} / \mathrm{L}$ & 0,009 & 3 \\
16 & Nikel Total & $\mathrm{mg} / \mathrm{L}$ & $<0,0413$ & 0,5 \\
17 & BOD & $\mathrm{mg} / \mathrm{L}$ & 240 & 150 \\
\hline
\end{tabular}

Berdasarkan tabel diatas, dapat diketahui bahwa limbah cair tersebut tercemar dan tidak layak dibuang langsung ke perairan karena nilai COD, BOD, dan TSS nya melebihi baku mutu. Hasil uji limbah juga menunjukkan parameter yang melebihi baku mutu adalah parameter yang diuji pada air limbah domestik. Maka dari itu baku mutu yang saya pakai untuk tahapan penelitian selanjutnya adalah baku mutu air limbah domestik sesuai dengan Peraturan Menteri Lingkungan Hidup Kehutanan Republik Indonesia Nomor: P.68/Menlhk/Setjen/Kum.1/8/2016.

Dengan demikian air limbah ini perlu diberi perlakuan sebelum dibuang ke perairan. Pada penelitian ini perlakuan limbah yang saya lakukan adalah dengan sistem constructed wetland dan menggunakan tanaman kayu apu (Pistia stratiotes L.). Tanaman kayu apu (Pistia stratiotes L.) yang saya gunakan adalah tanaman kayu apu (Pistia stratiotes L.) yang berusia 4 minggu, namun sebelum dilakukan penelitian saya melakukan aklimatisasi terlebih dahulu selama 2 minggu. Maka usia tanaman pada saat akan dilakukan penelitian sudah berusia 6 minggu. 
Penelitian menggunakan tanaman Kayu Apu (Pistia stratiotes L.) dengan sistem constructed wetland sudah pernah dilakukan namun belum ada penelitian yang menggunakan air limbah domestik sebagai sampel. Maka dari itu penelitian ini dilakukan sebagai wujud untuk mengurangi beban pencemar air sungai. Dari penelitian yang pernah ada saya melihat bahwa penelitian tersebut menggunakan tanaman Kayu Apu (Pistia stratiotes L.) yang jumlahnya lebih sedikit, yaitu 6 tanaman dan waktu yang digunakan dalam penelitian cukup panjang, yaitu 15 hari.

Untuk membuat penelitian ini berbeda dengan penelitian sebelumnya selain menggunakan sampel yang berbeda, saya melakukan modifikasi pada waktu penelitian saya, yaitu menguranginya menjadi 12 hari penelitian dan menggunakan 3 reaktor yang berisi tanaman kayu apu (Pistia stratiotes L.) yang jumlahnya bervariasi yaitu 4, 8 dan 12 tanaman. Sistem pengolahan limbah wetlands ini hanya membutuhkan bak-bak (kolam) sederhana saja yang isinya krikil, tanah dan pasir, sehingga tidak membutuhkan biaya besar untuk membuat instalasi bangunannya. Pengolahan limbah mengandalkan kinerja tanaman dan mikroba yang terdapat pada akar tanaman yang bekerja secara alamiah, sehingga tidak membutuhkan sistem pengoperasian yang rumit dan dapat menekan biaya operasionalnya. Hasil penelitin yang saya lakukan dapat dilihat pada pembahasan dibawah ini.

\subsection{Pembahasan}

\subsubsection{Pengaruh Variasi Jumlah Tanaman pada Hari ke-3 Terhadap Penurunan BOD, COD dan TSS dengan Constructed Wetland}

Optimasi waktu kontak tanaman untuk mengetahui penurunan maksimum kadar BOD, COD, dan TSS pada hari ketiga dengan variasi jumlah tanaman 4, 8, dan 12. Hasil analisis kadar BOD, COD dan TSS terhadap variasi tanaman dapat dilihat pada tabel 2.

Tabel 2. Hasil Pengujian Air Limbah Pada Hari ke-3

\begin{tabular}{|c|l|c|c|c|c|c|}
\hline \multirow{2}{*}{ No $_{\mathbf{0}}$} & Parameter & \multirow{2}{*}{ Satuan } & Baku & \multicolumn{3}{|c|}{ Jumlah tanaman } \\
\cline { 5 - 7 } & & & Mutu & $\mathbf{4}$ & $\mathbf{8}$ & 12 \\
\hline 1 & BOD & $\mathrm{mg} / \mathrm{L}$ & 30 & 170 & 150 & 120 \\
\hline 2 & COD & $\mathrm{mg} / \mathrm{L}$ & 30 & 271,46 & 239,52 & 191,62 \\
\hline 3 & TSS & $\mathrm{mg} / \mathrm{L}$ & 100 & 337,73 & 278,11 & 206,11 \\
\hline
\end{tabular}

Tabel 2 menunjukkan hasil penurunan kadar BOD, COD dan TSS pada hari ketiga berbeda-beda karena jumlah tanaman yang digunakan berbeda setiap batchnya.

Pada constructed wetland dengan 4 tanaman didapat hasil pada BOD $170 \mathrm{mg} / \mathrm{L}(29,17 \%)$, COD 271,46 mg/L (15,17\%), dan TSS 337,73 mg/L (22,62\%).

Pada constructed wetland dengan 8 tanaman didapat hasil pada BOD $150 \mathrm{mg} / \mathrm{L}(37,5 \%)$, COD 239,52 mg/L (25,15), dan TSS 278,11 mg/L (36,28\%).

Pada constructed wetland dengan 12 tanaman didapat hasil pada BOD $120 \mathrm{mg} / \mathrm{L}(50 \%)$, COD 162,87 mg/L (40,12\%), dan TSS 206,11 mg/L (52,77\%). 


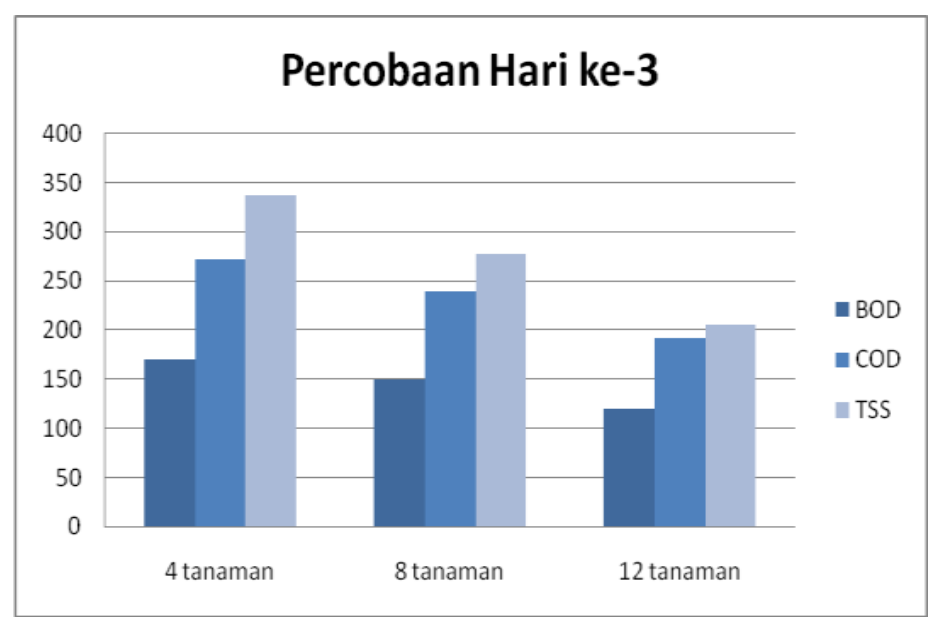

Gambar 3. Grafik Hasil Pengukuran Uji BOD, COD dan TSS Pada Hari ke-3 Percobaan

Berdasarkan grafik diatas dapat kita lihat bahwa hasil penelitian pada hari ketiga, saat umur tanaman 6 minggu 3 hari sudah menunjukkan adanya penurunan kadar BOD, COD dan TSS walaupun masih diatas baku mutu air limbah domestik. Hasil uji BOD dan COD memiliki penurunan yang sejalan karena limbah domestik bersifat biodegradable (dapat terdegradasi secara biologi). Dan proses filtrasi dilakukan oleh media dan akar tanaman yang terdapat dalam reaktor, dimana proses tersebut terjadi karena kemampuan partikel-partikel media maupun sistem perakaran membentuk filter yang dapat menahan partikel- partikel solid yang terdapat dalam air limbah.

Namun dikarenakan wadah constructed wetland yang tidak tinggi, membuat jarak tanaman dan media hanya $6 \mathrm{~cm}$, menyebabkan tergganggunya pertumbuhan akar-akar tanaman Kayu Apu (Pistia stratiotes. L). Sehingga membuat akar tanaman tidak dapat bekerja dengan maksimal. Dapat kita lihat juga bahwa jumlah tanaman mempengaruhi penurunan kadar BOD, COD dan TSS dalam air limbah. Semakin banyak tanaman menunjukkan semakin baik hasil yang didapatkan. Namun, waktu tinggal penanaman hanya 3 hari sehingga tanaman Kayu Apu (Pistia stratiotes. L) dan constructed wetland belum bekerja dengan maksimal serta mikroorganisme yang terdapat pada akar tanaman memerlukan waktu untuk mendegradasi bahan-bahan organik yang terkandung dalam air limbah tersebut.

\subsubsection{Variasi Jumlah Tanaman Pada Hari Ke-6 Terhadap Penurunan BOD, COD dan TSS dengan Constructed Wetland}

Optimasi waktu kontak tanaman untuk mengetahui penurunan maksimum kadar BOD, COD, dan TSS pada hari keenam dengan variasi jumlah tanaman 4, 8, dan 12. Hasil analisis kadar BOD, COD dan TSS terhadap variasi tanaman dapat dilihat pada tabel 3 .

Tabel 3. Hasil Pengujian Air Limbah Pada Hari ke-6

\begin{tabular}{|c|l|c|c|c|c|c|}
\hline \multirow{2}{*}{ No } & Parameter & \multirow{2}{*}{ Satuan } & Baku & \multicolumn{4}{|c|}{ Jumlah tanaman } \\
\cline { 4 - 7 } & & & Mutu & $\mathbf{4}$ & $\mathbf{8}$ & $\mathbf{1 2}$ \\
\hline 1 & BOD & $\mathrm{mg} / \mathrm{L}$ & 30 & 90 & 80 & 60 \\
\hline 2 & COD & $\mathrm{mg} / \mathrm{L}$ & 30 & 198,37 & 164,50 & 119,35 \\
\hline 3 & TSS & $\mathrm{mg} / \mathrm{L}$ & 100 & 273,24 & 197,54 & 155,33 \\
\hline
\end{tabular}

Tabel 3 menunjukkan hasil penurunan kadar BOD, COD dan TSS pada hari keenam berbeda-beda karena jumlah tanaman yang digunakan berbeda setiap batchnya. 
Pada constructed wetland dengan 4 tanaman didapat hasil pada BOD $90 \mathrm{mg} / \mathrm{L}(62,50 \%)$, COD 198,37 mg/L (38,01\%), dan TSS 273,24 mg/L (37,39\%).

Pada constructed wetland dengan 8 tanaman didapat hasil pada BOD $80 \mathrm{mg} / \mathrm{L}(66,67 \%)$, COD 164,50 mg/L (48,59\%), dan TSS 197,54 mg/L (54,74\%).

Pada constructed wetland dengan 12 tanaman didapat hasil pada BOD $60 \mathrm{mg} / \mathrm{L}(75 \%)$, COD 119,35 mg/L (62,70\%), dan TSS 155,33 mg/L (64,41\%).

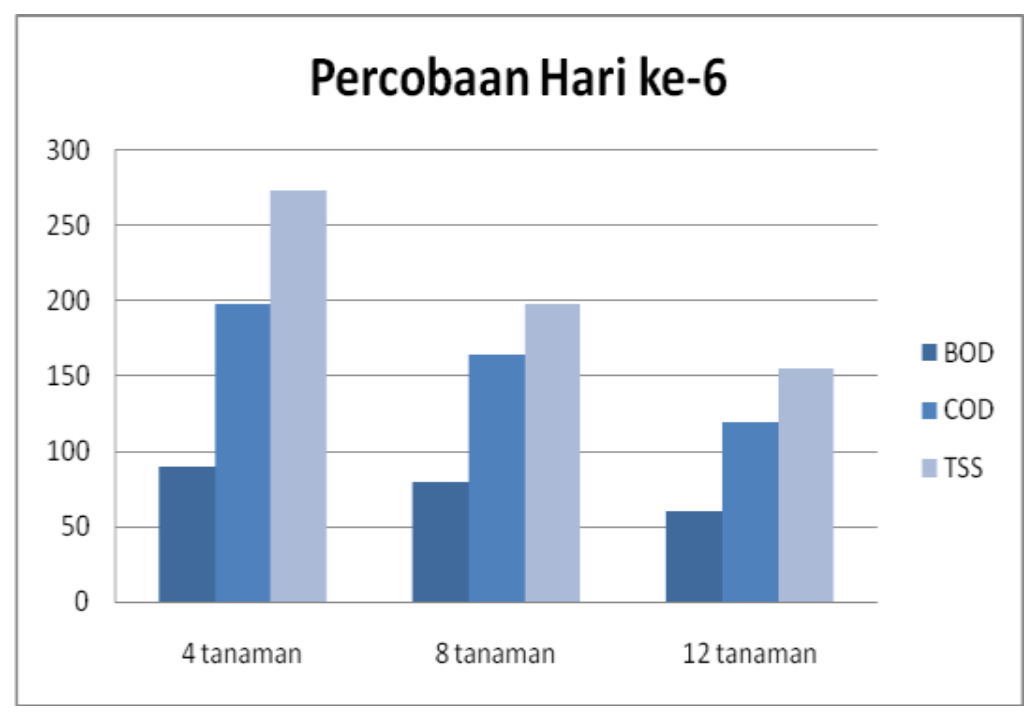

Gambar 4. Grafik hasil pengukuran uji BOD, COD dan TSS pada hari ke- 6 percobaan

Berdasarkan grafik diatas dapat kita lihat bahwa hasil penelitian pada hari keenam, saat umur tanaman 6 minggu 6 hari penanaman menunjukkan penurunan yang sudah mencapai 50\%, kadar BOD, COD dan TSS sudah memenuhi baku mutu air limbah domestik. Hasil uji BOD dan COD memiliki penurunan yang sejalan karena limbah domestik bersifat biodegradable (dapat terdegradasi secara biologi). Dan proses filtrasi dilakukan oleh media dan akar tanaman yang terdapat dalam reaktor, dimana proses tersebut terjadi karena kemampuan partikel-partikel media maupun sistem perakaran membentuk filter yang dapat menahan partikel-partikel solid yang terdapat dalam air limbah.

Namun dikarenakan wadah constructed wetland yang tidak tinggi, membuat jarak tanaman dan media hanya $6 \mathrm{~cm}$, menyebabkan tergganggunya pertumbuhan akar-akar tanaman Kayu Apu (Pistia stratiotes. L). Sehingga membuat akar tanaman tidak dapat bekerja dengan maksimal. Dapat kita lihat juga bahwa jumlah tanaman mempengaruhi penurunan kadar BOD, COD dan TSS dalam air limbah. Semakin banyak tanaman menunjukkan semakin baik hasil yang didapatkan. Waktu tinggal penanaman yang semakin lama yaitu 6 hari membuat tanaman Kayu Apu (Pistia stratiotes. L) dan constructed wetland semakin bekerja dengan baik serta mikroorganisme yang terdapat pada akar tanaman bekerja semakin cepat untuk mendegradasi bahan-bahan organik dalam air limbah tersebut.

\subsubsection{Pengaruh Variasi Jumlah Tanaman Pada Hari Ke-9 Terhadap Penurunan BOD, COD dan TSS dengan Constructed Wetland}

Optimasi waktu kontak tanaman untuk mengetahui penurunan maksimum kadar BOD, COD, dan TSS pada hari kesembilan dengan variasi jumlah tanaman 4, 8, dan 12. Hasil analisis kadar BOD, COD dan TSS terhadap variasi tanaman dapat dilihat pada tabel 4

Tabel 4. Hasil Pengujian Air Limbah Pada Hari ke-9 
Jurnal SEOI - Fakultas Teknik Universitas Sahid Jakarta

Vol 2 edisi 1 tahun 2020

\begin{tabular}{|c|l|c|c|c|c|c|}
\hline \multirow{2}{*}{ No } & Parameter & Satuan & Baku & \multicolumn{4}{|c|}{ Jumlah tanaman } \\
\cline { 4 - 6 } & & & Mutu & $\mathbf{4}$ & $\mathbf{8}$ & $\mathbf{1 2}$ \\
\hline 1 & BOD & $\mathrm{mg} / \mathrm{L}$ & 30 & 30 & 30 & 20 \\
\hline 2 & COD & $\mathrm{mg} / \mathrm{L}$ & 30 & 80,64 & 67,74 & 38,71 \\
\hline 3 & TSS & $\mathrm{mg} / \mathrm{L}$ & 100 & 120,15 & 91,00 & 72,40 \\
\hline
\end{tabular}

Tabel 4 menunjukkan hasil penurunan kadar BOD, COD dan TSS pada hari kesembilan berbeda-beda karena jumlah tanaman yang digunakan berbeda setiap batchnya.

Pada constructed wetland dengan 4 tanaman didapat hasil pada BOD $30 \mathrm{mg} / \mathrm{L}(87,5 \%)$, COD 80,64 mg/L (74,80\%), dan TSS 120,15 mg/L (72,47\%).

Pada constructed wetland dengan 8 tanaman didapat hasil pada BOD $30 \mathrm{mg} / \mathrm{L}(87,5 \%)$, COD 67,74 mg/L (78,83\%), dan TSS $91 \mathrm{mg} / \mathrm{L}$ (70,15\%).

Pada constructed wetland dengan 12 tanaman didapat hasil pada BOD $20 \mathrm{mg} / \mathrm{L}(91,67 \%)$, COD 38,71 mg/L (87,90\%), dan TSS 72,40 mg/L (83,41\%).

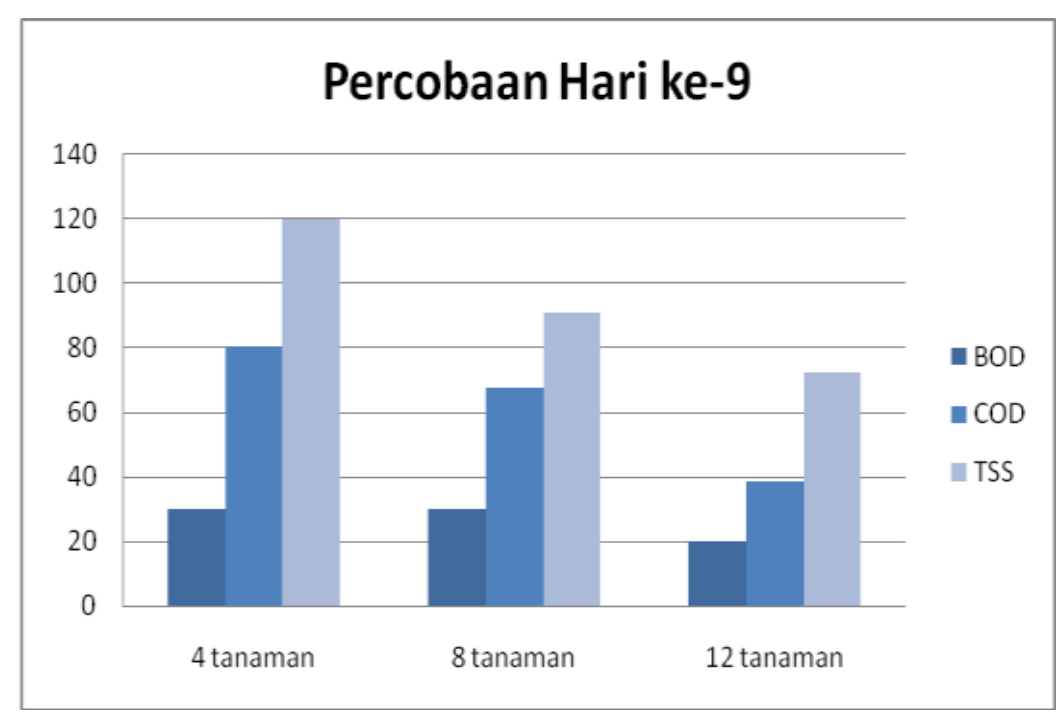

Gambar 5. Grafik hasil pengukuran uji BOD, COD dan TSS pada hari ke- 9 percobaan

Berdasarkan grafik diatas dapat kita lihat bahwa hasil penelitian pada hari kesembilan penanaman, saat umur tanaman 7 minggu 2 hari menunjukkan penurunan yang sudah mencapai lebih dari 50\% kadar BOD, COD dan TSS sudah memenuhi baku mutu air limbah domestik. Hasil uji BOD dan COD memiliki penurunan yang sejalan karena limbah domestik bersifat biodegradable (dapat terdegradasi secara biologi). Dan proses filtrasi dilakukan oleh media dan akar tanaman yang terdapat dalam reaktor, dimana proses tersebut terjadi karena kemampuan partikel-partikel media maupun sistem perakaran membentuk filter yang dapat menahan partikel-partikel solid yang terdapat dalam air limbah.

Namun dikarenakan wadah constructed wetland yang tidak tinggi, membuat jarak tanaman dan media hanya $6 \mathrm{~cm}$, menyebabkan tergganggunya pertumbuhan akar-akar tanaman Kayu Apu (Pistia stratiotes. L). Sehingga membuat akar tanaman tidak dapat bekerja dengan maksimal. Dapat kita lihat juga bahwa jumlah tanaman mempengaruhi penurunan kadar BOD, COD dan TSS dalam air limbah. Semakin banyak tanaman menunjukkan semakin baik hasil yang didapatkan. Waktu tinggal penanaman yang semakin lama, yaitu 9 hari membuat tanaman Kayu Apu (Pistia stratiotes. L) dan constructed wetland semakin bekerja dengan baik serta mikroorganisme yang bekerja semakin cepat untuk mendegradasi bahan-bahan organik dalam air limbah tersebut. Dan pada hari kesembilan merupakan waktu yang paling optimum tanaman 
kayu apu (Pistia stratiotes. L) bekerja, karena penyisihan paling besar dihasilkan pada hari kesembilan.

\subsubsection{Variasi Jumlah Tanaman Pada Hari Ke-12 Terhadap Penurunan BOD, COD dan TSS dengan Constructed Wetland}

Optimasi waktu kontak tanaman untuk mengetahui penurunan maksimum kadar BOD, COD, dan TSS pada hari keduabelas dengan variasi jumlah tanaman 4, 8, dan 12. Hasil analisis kadar BOD, COD dan TSS terhadap variasi tanaman dapat dilihat pada tabel 5.

Tabel 5. Hasil Pengujian Air Limbah Pada Hari ke-12

\begin{tabular}{|c|l|c|c|c|c|c|}
\hline \multirow{2}{*}{$N_{0}$} & Parameter & \multirow{2}{*}{ Satuan } & Baku & \multicolumn{3}{|c|}{ Jumlah tanaman } \\
\cline { 4 - 7 } & & & Mutu & $\mathbf{4}$ & $\mathbf{8}$ & $\mathbf{1 2}$ \\
\hline 1 & BOD & $\mathrm{mg} / \mathrm{L}$ & 30 & 20 & 10 & 10 \\
\hline 2 & COD & $\mathrm{mg} / \mathrm{L}$ & 30 & 31,94 & 22,36 & 15,97 \\
\hline 3 & TSS & $\mathrm{mg} / \mathrm{L}$ & 100 & 32,62 & 23,10 & 17,66 \\
\hline
\end{tabular}

Tabel 5 menunjukkan hasil penurunan kadar BOD, COD dan TSS pada hari keduabelas berbeda-beda karena jumlah tanaman yang digunakan berbeda setiap batchnya.

Pada constructed wetland dengan 4 tanaman didapat hasil pada BOD $20 \mathrm{mg} / \mathrm{L}(91,67 \%)$, COD 31,94 mg/L (90,02\%), dan TSS 32,62 mg/L (92,52\%).

Pada constructed wetland dengan 8 tanaman didapat hasil pada BOD $10 \mathrm{mg} / \mathrm{L}(95,83 \%)$, COD 22,36 mg/L (93,01\%), dan TSS 23,10 mg/L (94,71\%).

Pada constructed wetland dengan 12 tanaman didapat hasil pada BOD $10 \mathrm{mg} / \mathrm{L}(95,83 \%)$, COD 15,97 mg/L (95,01\%), dan TSS 17,66 mg/L (96,09\%).

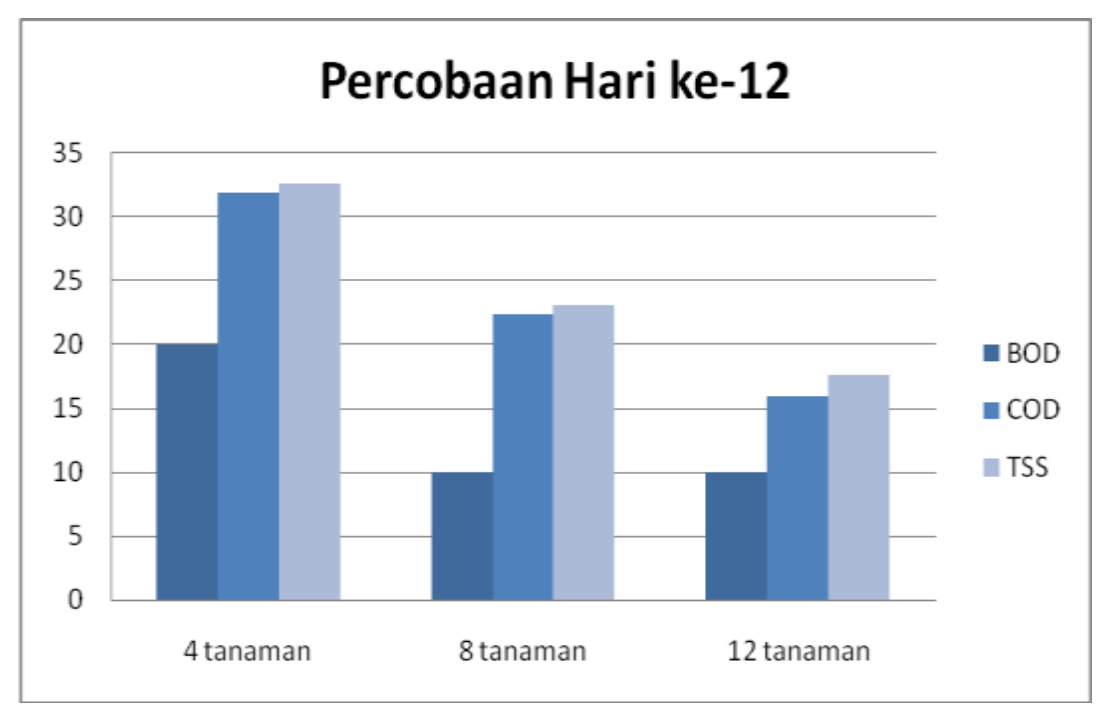

Gambar 6. Grafik hasil pengukuran uji BOD, COD dan TSS pada hari ke-12 percobaan

Berdasarkan grafik diatas dapat kita lihat bahwa hasil penelitian pada hari keduabelas, saat umur tanaman 7 minggu 5 hari penanaman menunjukkan penurunan yang mencapai $90 \%$ lebih, kadar BOD, COD dan TSS sudah memenuhi baku mutu air limbah domestik bahkan memenuhi baku mutu air sungai, sehingga jika limbah dibuang kebadan sungai tidak akan 
mencemari sungai tersebut. Sungai tempat pembuangan akhir air ini sudah tercemar, sehingga termasuk kedalam air sungai kelas 2 (dua). Walaupun tergolong kelas 2, air sungai ini masih dapat digunakan sebagai prasarana/sarana kegiatan rekreasi air, pembudidayakan ikan air tawar, peternakan, air untuk mengairi pertanaman, dan peruntukan lain yang mensyaratkan mutu air yang sama dengan kegunaan tersebut.

Hasil uji BOD dan COD memiliki penurunan yang sejalan karena limbah domestik bersifat biodegradable (dapat terdegradasi secara biologi). Dan proses filtrasi dilakukan oleh media dan akar tanaman yang terdapat dalam reaktor, dimana proses tersebut terjadi karena kemampuan partikel-partikel media maupun sistem perakaran membentuk filter yang dapat menahan partikel- partikel solid yang terdapat dalam air limbah. Namun dikarenakan wadah constructed wetland yang tidak tinggi, membuat jarak tanaman dengan media hanya $6 \mathrm{~cm}$, menyebabkan tergganggunya pertumbuhan akar-akar tanaman Kayu Apu (Pistia stratiotes. L). Sehingga membuat akar tanaman tidak dapat bekerja dengan maksimal. Pada hari ke-12 juga tanaman kayu apu (Pistia stratiotes. L) sudah banyak yang menguning, sehingga mengurangi daya adsorpsi tanaman. Maka dari itu, usia tanaman sangat penting agar mampu bekerja maksimal. Untuk memperlambat jenuhnya tanaman, proses aklimatisasi dapat dilakukan hanya pada air limbah saja, selama 1 minggu.

Namun, dengan semakin banyaknya tanaman menunjukkan semakin baik hasil yang didapatkan. Dapat kita lihat dari hasil penyerapannya terhadap kadar COD, BOD, dan TSS. Sehingga dapat dikatakan bahwa reaktor dengan jumlah tanaman 12 dan waktu tinggal 12 hari merupakan yang paling efektif sehingga membuat tanaman Kayu Apu (Pistia stratiotes. L) dan constructed wetland bekerja dengan baik serta mikroorganisme yang semakin cepat untuk mendegradasi bahan-bahan organik dalam air limbah tersebut.

\section{Kesimpulan}

\subsection{Kesimpulan}

Berdasarkan hasil penelitian dan pembahasan yang telah dibuat maka dapat disimpulkan sebagai berikut:

Jumlah tanaman Kayu Apu (Pistia stratiotes. L) terbaik dalam pengolahan limbah adalah reaktor dengan 12 tanaman. Dikarenakan semakin banyak jumlah tanaman yang digunakan, maka semakin besar penyerapan yang dihasilkan. Efisensi penyisihan yang dihasilkan reaktor dengan 12 tanaman dari waktu kewaktu, menghasilkan penyisihan tertinggi. Pada hari ketiga didapat hasil pada BOD $160 \mathrm{mg} / \mathrm{L}$ (50\%), COD 162,87 mg/L (40,12\%), dan TSS 206,11 mg/L $(52,77 \%)$. Pada hari keenam didapat hasil pada BOD $60 \mathrm{mg} / \mathrm{L}(75 \%)$, COD 119,35 mg/L $(62,70 \%)$, dan TSS $155,33 \mathrm{mg} / \mathrm{L}(64,41 \%)$. Pada hari kesembilan didapat hasil pada BOD 20 $\mathrm{mg} / \mathrm{L}$ (91,67\%), COD 38,71 mg/L (87,90\%), dan TSS 72,40 mg/L (83,41\%). Pada hari keduabelas didapat hasil pada BOD $10 \mathrm{mg} / \mathrm{L}(95,83 \%)$, COD 15,97 mg/L (95,01\%), dan TSS 17,66 mg/L (96,09\%).

Pengaruh waktu kontak tanaman Kayu Apu (Pistia stratiotes. L) yang paling efisien yaitu pada hari ke-12 didapat hasil sebagai berikut, reaktor 4 tanaman didapat hasil pada BOD 20 $\mathrm{mg} / \mathrm{L}(91,67 \%)$, COD 31,94 mg/L (90,02\%), dan TSS 32,62 mg/L (92,52\%). Reaktor dengan 8 tanaman didapat hasil pada BOD $10 \mathrm{mg} / \mathrm{L}(95,83 \%)$, COD 22,36 mg/L (93,01\%), dan TSS 23,10 mg/L (94,71\%). Reaktor dengan 12 tanaman didapat hasil pada BOD $10 \mathrm{mg} / \mathrm{L}(95,83 \%)$, COD 15,97 mg/L (95,01\%), dan TSS 17,66 mg/L (96,09\%).

Waktu optimum pada percobaan ini adalah hari ke-9. Dimana constructed wetland dan tanaman Kayu Apu (Pistia stratiotes L.) bekerja sangat baik. Sehingga persen removal yang dihasilkan dari semua waktu, yang mengalami peningkatan paling besar adalah pada percobaan 
hari ke-9. Demikian hasilnya, pada constructed wetland dengan 4 tanaman didapat hasil pada BOD $30 \mathrm{mg} / \mathrm{L}$ (87,5\%), COD 80,64 mg/L (74,80\%), dan TSS 120,15 mg/L (72,47\%). Pada constructed wetland dengan 8 tanaman didapat hasil pada BOD $30 \mathrm{mg} / \mathrm{L}$ (87,5\%), COD 67,74 $\mathrm{mg} / \mathrm{L}(78,83 \%)$, dan TSS $91 \mathrm{mg} / \mathrm{L}(70,15 \%)$. Pada constructed wetland dengan 12 tanaman didapat hasil pada BOD $20 \mathrm{mg} / \mathrm{L}(91,67 \%)$, COD 38,71 mg/L (87,90\%), dan TSS 72,40 mg/L $(83,41 \%)$.

\subsection{Saran}

1. Penelitian sebaiknya dilakukan dalam reaktor yang tingginya lebih dari $24 \mathrm{~cm}$. Agar akar tanaman Kayu Apu (Pistia stratiotes L.) dapat tumbuh dengan baik.

2. Tanaman Kayu Apu (Pistia stratiotes L.) sebaiknya tidak diletak dibawah matahari langsung, karena dapat merusak tanaman ini terlihat dari perubahan daun-daunnya yang menguning.

3. Tanaman Kayu Apu (Pistia stratiotes L.) yang digunakan sebaiknya yang usianya kurang dari 4 bulan. Agar tidak melewati masa produktif tanaman tersebut.

4. Aklimatisasi cukup dilakukan pada air yang akan kita uji (limbah) dan waktunya cukup 1 minggu saja. Dikarenakan, terlalu lama waktu aklimatisasi akan membuat tanaman Kayu Apu (Pistia stratiotes L.) cepat jenuh.

5. Penelitian ini cukup efisien karena berhasil menurunkan kadar COD, BOD dan TSS pada air limbah tetapi tidak efisien terhadap waktu dikarenakan waktu yang diperlukan dalam penurunanya cukup lama yaitu, 12 hari.

6. Pengolahan limbah secara biologis sangat diharapkan, karena tidak mencemari lingkungan. Maka dari itu, jika constructed wetland ingin dijadikan sebagai pengolahan limbah domestik. Besar constructed wetland yang dibutuhkan adalah $1,7 \mathrm{~m}$ x 1,7m x 1,7m. Dapat dilihat pada lampiran 4.

7. Diharapkan semua laboratorium ataupun instansi yang menghasilkan limbah B3 yang ada di kota Bekasi. Dapat mengolah limbahnya sesuai IKU yang ada, tertera dalam Perda 09 Tahun 2013 Tentang Pengelolaan Limbah Bahan Berbahaya \& Beracun serta Limbah Industri lain. UPTD laboratorium sendiri juga sudah melakukan sesuai denan IKU, dengan memberikan limbah B3 ke perusahaan pengolahan limbah yang sudah terakreditasi.

\section{Daftar Pustaka}

Ismuyanto, B. (2010). Pencemaran Karena Pembangunan (Materi Seminar). Jakarta

Peraturan Menteri Lingkungan Hidup dan Kehutanan Republik Indonesia Nomor 68, (2016). tentang Baku Mutu Air Limbah Domestik

Perda Kota Bekasi No 09, (2013). Tentang Pengelolaan Limbah Bahan Berbahaya \& Beracun serta Limbah Industri lain

Safitri, R. (2009). Phytoremidiasi Greywater Dengan Tanaman Kayu Apu (Pistia stratiotes L.) dan Tanaman Kiambang (Salvinia molesta) Serta Pemanfaatannya Untuk Tanaman Selada (Lactuca sativa) Secara Hidroponik. Skripsi. Institut Pertanian Bogor. Bogor

Zidan, A. R. A., M. M. El Gamal, A.A. Rashed, M.A.Eid.(2015).Waste water treatmentin horizontal subsurface flow constructed wetlands using different media(setup stage).Water Science,29:1-10. 